type. Arch. Gerontol. Geriatrics (Supplement 5):47-50.

Predny, M.L. and D. Relf. 2000. Interactions between elderly adults and preschool children in a horticultural therapy research program. HortTechnology 10:64-70.

Relf, P.D. 1978. Horticulture as a recreational activity. Amer. Health Care Assn. J. 4(5):68-71.

Relf, P.D. 1994. Gardening in raised beds and containers for older gardeners and individuals with physical disabilities. Va. Coop. Ext. Publ. 426-020.

Relf, D. and S. Dorn. 1995. Horticulture: Meeting the needs of special populations. HortTechnology 5:94-103.

Salari, S.M. and M. Rich. 2001. Social and environmental infantilization of aged persons: Observations in two adult day care centers. Intl. J. Aging Human Dev. 52:115134.

Sarno, M.T. and N. Chambers. 1997. A Horticulture Therapy program for individuals with acquired aphasia. Activities Adaptation and Aging 22:81-91.

Seifert, L.S. 1998. Structured activities reveal residual function in Alzheimer's type dementia. Clin. Gerontologist 19:35-43.

Sommer, R. and B. Sommer. 1980. A practical guide to behavioral research. Oxford Univ. Press, New York.

Spaull, D., C. Leach, and I. Frampton. 1998. An evaluation of the effects of sensory stimulation with people who have dementia. Behavioral Cognitive Psychotherapy 26:77-86.

Tariot, P.N. 1996. Treatment strategies for agitation and psychosis in dementia. J. Clin. Psychol. 57:21-29.

Thomas, W. 1996. Life worth living: How someone you love can still enjoy life in a nursing home: The Eden alternative in action. VanderWyk \& Burnham, Acton, Mass.

Thomas, W. 2002. Honoring excellence in our Edenized facilities. Eden Alternative. 22 Mar. 2002. <http:// www.edenalt.com/home/index.htm>.

Vining, J. and J.J. Stevens. 1986. The assessment of landscape quality: Major methodological considerations, p. 167186. In: R.C. Smardon, J.R. Palmer, and J.P. Felleman (eds.). Foundations for visual project analysis. Wiley, New York.

Zarit, S.H. and J.M. Zarit. 1998. Mental disorders in older adults: Fundamentals of assessment and treatment. Guilford Press, New York.

Zeisel, J. 1981. Inquiry by design: Tools for environment-behavior research. Brooks Cole, Monterey, Calif.

\section{In-row Spacing and Cultivar Affects Ear Yield and Quality of Early-planted Sweet Corn}

\author{
Anusuya Rangarajan, ${ }^{1}$ \\ Betsy Ingall, ${ }^{2}$ \\ Michael Orfanedes, ${ }^{3}$ and \\ David Wolfe ${ }^{4}$
}

Additional IndeX words. plant population, ear length, Zea mays, varieties, stand establishment

Summary. Early-planted fresh market sweet corn (Zea mays) is prone to nonuniform ear length and quality due to uneven germination in cool soils. Growers compensate by reducing in-row spacing at seeding, to increase final plant stand. This risk management strategy was suspected to be reducing quality of early-planted sweet corn, based upon buyer feedback. Four experiments were conducted in upstate New York, to examine the effects of in-row spacing and cultivar on early-planted sweet corn ear yield, length and uniformity. Cultivars examined included 'Temptation' (4 years), 'Sweet Symphony' (3 years) and 'Seneca Spring' ( 2 years). In-row spacings tested ranged from 6 to 9 inches $(15.2$ to $22.9 \mathrm{~cm})$, using a 30 -inch $(76.2-\mathrm{cm})$ between-row spacing. In-row spacing and cultivar influenced marketable yield, husked ear weight and length of early-planted corn, but the extent varied by year. Despite improvements in individual ear weight and length at wider in-row spacing, marketable yield was usually

\footnotetext{
This research supported in part by grants from the Pennsylvania Vegetable Research and Development Fund, New York Fresh Market Vegetable Research Fund, the Eden Valley Growers Cooperative (NY) and USDA Hatch Project 145406

${ }^{1}$ Assistant professor, Department of Horticulture, Cornell University, Ithaca NY 14853.

${ }^{2}$ Research technician, Department of Horticulture, Cornell University, Ithaca NY 14853.

${ }^{3}$ Extension educator. current address: University of Florida Cooperative Extension, Ft. Lauderdale.

${ }^{4}$ Associate professor, Department of Horticulture,
} Cornell University, Ithaca NY 14853. higher at more narrow spacings. Increases in ear weight at wider spacings were usually associated with increases in weight of the outer, green husk. Average ear length of a cultivar varied between 0.2 and 0.6 inches $(0.5$ to $1.5 \mathrm{~cm})$ in response to spacing. If ears longer than 7 inches $(17.8 \mathrm{~cm})$ were desired, $40 \%$ to $60 \%$ of ears satisfied this criteria if harvested from plants grown at 8 -inch $(20.3-\mathrm{cm})$ in-row spacing or a plant population of 26,000 plants/acre $(64,200$ plants/ha). Ear weight and length of 'Seneca Spring' was not as affected by the in-row spacing treatments compared to the other two cultivars, perhaps due to the small size of this cultivar. Selection of smaller sized sweet corn cultivars for planting at high plant populations (6-inch inrow spacing) may reduce the variation in ear weight under challenging early season conditions. For cultivars with similar growth characteristics and maturities of 'Temptation' and 'Sweet Symphony,' a minimum in-row spacing of 8 to 9 inches or a plant population of 23,200 to 26,000 plants/acre $(57,300$ to 64,200 plants/ha) was recommended to minimize variation in ear yield and quality from first bareground plantings in the northeastern United States.

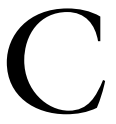
ool soil temperatures and climatic conditions during first early, bareground plantings of sweet corn can cause poor germination and reduced stands. Some growers may compensate by increasing seeding rates for early plantings. However, at high population densities, ear quality can be negatively affected by reduced light interception and increased competition for soil resources (Wolfe et al., 1997). This earlyplanted corn targets a high-value market. Some buyers in the northeastern United States, however, have complained about nonuniform ear appearance and length of locally grown, early sweet corn (personal communication). In an informal survey of current practices, growers reported using in-row spacings from 6 to 10 inches ( 15.2 to $25.4 \mathrm{~cm})(30$-inch between-row spacing) for their first bareground planting of sweet corn. This represented a range of plant populations from 20,900 to 34,800 plants /acre $(51,600$ to 86,000 plants/ha).

Most published research on sweet corn spacing and plant populations 
was conducted between 1950 and 1970 , using predominately sugary (su) type sweet corn cultivars (main season) selected for the processing industry (Andrew, 1967; Bailey, 1941; Dolan and Christopher, 1952; Enzie, 1942; Freyman et al., 1972; Mack, 1978; Vittum et al., 1959) and in later studies sugary enhanced (se) (Morris et al., 2000) or shrunken-2 ( $\left.\mathrm{sh}_{2}\right)$ type cultivars (Hanna and Story, 1992; White, 1984). Increased plant populations (by reducing in-row spacings) were tested to determine if yields could be increased without compromising ear size or the kernel to cob ratio. On average, closer in-row spacing [tests ranged from 4 to 9 inches (10.2 to $22.9 \mathrm{~cm})$ ] reduced ear length up to 0.4 inches $(1 \mathrm{~cm})$ in su type sweet corn. More important was the increase in variation of ear length from plants established at closer spacings (Andrew, 1967; Dolan and Christopher, 1952; White, 1984). A recent study examined effects of populations on yield and ear length of main season sweet corn cultivars (se and su) planted in early June in the northeastern U.S. (Morris et al., 2000). Most cultivars yielded best at a population ranging from 24,000 to 28,000 plants/acre $(59,300$ to 69,200 plants /ha $)$, assuming 6-inch ears were marketable. If ears at least 7 inches long were required, a lower population of 20,000 to 24,000 plants/acre $(35,500$ to 59,300 plants / ha) was recommended, depending on the cultivar.

Recommended in-row spacings for sweet corn grown in New York and other parts of the northeastern U.S. range from 8 to 12 inches $(20.3$ to $30.5 \mathrm{~cm})$, based upon a 30 -inch between-row spacing (Garrison, 2002; Orzelek et al., 2001; Reiners et al., 2001). A narrower in-row spacing (higher plant population) is suggested for earlier planted corn, due to potential reduced germination rate in cool soil, smaller plant size and the single ear per stalk trait of early varieties. The responses of yield and ear quality of different fresh market sweet corn types to these populations at early plantings is unknown. The objectives of these studies were to evaluate the effect of in-row spacing on ear yield and quality and to determine the most narrow inrow spacing (or highest plant population) that optimized these traits for three fresh market sweet corn cultivars commonly planted at the first early bareground planting in the northeastern U.S.

\section{Materials and methods}

Four experiments were conducted from 1998 through 2001 to compare sweet corn cultivar response to in-row spacing after planting at the earliest spring date (based upon soil temperature $\left[50{ }^{\circ} \mathrm{F}\left(10^{\circ} \mathrm{C}\right)\right]$ and moisture conditions) for bareground culture in upstate New York. All trials were irrigated to supplement rainfall and provide a minimum of 1 inch/acre (2.5 $\left.\mathrm{cm} \cdot \mathrm{ha}^{-1}\right)$ of water per week. The cultivars were selected based on recommendations from growers as commonly used for early bareground plantings in upstate New York. 'Temptation' (homozygous se; Seminis Vegetable Seeds, Oxnard, Calif.)(tested in four experiments) and 'Sweet Symphony' (se $\mathbf{x}$ $\mathrm{sh}_{2}$ X su hybrid; Harris Moran Seed Co., Modesto, Calif.)(tested in three experiments), had similar maturities, 72 and $74 \mathrm{~d}$ to harvest, respectively. In 2000 and 2001, 'Seneca Spring' (homozygous se, $68 \mathrm{~d}$ to harvest, Seminis Vegetable Seeds) was added to examine if cultivar response to in-row spacing would be different from a smallsized genotype. All plantings were established using a 30-inch betweenrow spacing.

In Eden, N.Y. (1998), 'Temptation' was planted on $27 \mathrm{Apr}$. at in-row spacings of 7,8 and 9 inches. The experiment was planted on an Alton fine gravelly loam (loamy-skeletal, mixed, mesic Dystric Eutrudepts) that received a preplant incorporated fertilizer $[60 \mathrm{~N}-24 \mathrm{P}-52 \mathrm{~K} \mathrm{lb} / \operatorname{acre}(67.2 \mathrm{~N}-$ $\left.\left.26.9 \mathrm{P}-58.3 \mathrm{Kkg} \cdot \mathrm{ha}^{-1}\right)\right]$ and sidedressed with $60 \mathrm{lb} / \operatorname{acre}\left(67.2 \mathrm{~kg} \cdot \mathrm{ha}^{-1}\right)$ of $\mathrm{N}$ as ammonium nitrate when corn had six leaves. Four rows were planted for each treatment, in a randomized complete block design with three replications. All data was taken from $30 \mathrm{ft}$ $(9.1 \mathrm{~m})$ of a center row. All ears were once-over harvested from each plot, sorted based on marketability (appearance and fill) and weighed. A randomly selected subsample of 10 ears was husked (outer green husk removed, leaving only cob plus kernels) for weight and length determination.

On 11 May, 1999, 'Temptation' and 'Sweet Symphony' were seeded at the H.C. Thompson Research Farm (Freeville, N.Y.) on an Eel silt loam soil (fine-loamy, mixed, nonacid mesic Aquic Udifluvent) at the same in-row spacings tested in 1998. The cultivar 'Sweet Symphony' was added based upon grower concerns about variability observed in this cultivar at early plantings. Preplant incorporated fertilizer provided $40 \mathrm{~N}-16 \mathrm{P}-24 \mathrm{Klb} /$ acre $\left(44.8 \mathrm{~N}-17.9 \mathrm{P}-26.9 \mathrm{~K} \mathrm{~kg} \cdot \mathrm{ha}^{-1}\right)$ and corn was sidedressed with $60 \mathrm{lb} /$ acre of $\mathrm{N}$ as ammonium nitrate on 20 June. Plots were arranged as a randomized complete block design for cultivar and spacing, with four replicates. Seeds were precision planted at twice the target population using a vacuum seeder and then thinned to desired inrow spacing 2 weeks later. Four rows were planted for each treatment and all ears were harvested from a $30-\mathrm{ft}$ section of a center row. All ears were once-over harvested from each plot, sorted based upon marketability (appearance and fill) and weighed. The percent of harvested ears that were marketable and the percent of barren plants (not producing marketable ears) were calculated. A subsample of 20 marketable ears was husked (outer green husk removed, leaving only cob plus kernels) for weight and length determination. The percent of ears longer than 7 inches was calculated from ear length measurements.

In 2000 and 2001, a closer inrow spacing (6 inches) was compared with the 8-inch treatment. We suspected that even under irrigated conditions, closer in-row spacing for sweet corn (commonly used as a risk avoidance strategy in early planted corn) would significantly reduce ear weight and quality. We also added the cultivar Seneca Spring to determine if a smallersized cultivar could be used with very high plant populations to minimize variability of ears. On 10 May 2000 and 8 May 2001, 'Temptation,' 'Sweet Symphony,' and 'Seneca Spring' were seeded at the H.C. Thompson Vegetable Research Farm on a Howard gravelly loam soil (loamy-skeletal mixed semic Glossoboric Hapludalf) at two in-row spacings ( 6 and 8 inches). Seeding and plot establishment were as described in 1999. Preplant incorporated fertilizer provided $60 \mathrm{~N}-28 \mathrm{P}-$ $46.5 \mathrm{~K} \mathrm{lb} /$ acre $(67.2 \mathrm{~N}-31.4 \mathrm{P}-52.1 \mathrm{~K}$ $\mathrm{kg} \cdot \mathrm{ha}^{-1}$ ) and $\mathrm{N}$ sidedress (60 lb/acre) was applied on 22 June 2000 or 18 June 2001. All ears were harvested from $40 \mathrm{ft}(12.2 \mathrm{~m})$ of the center rows and evaluated as described in 1999. At the end of each experiment, 10 consecutive plants from each plot were cut 
at the soil line for dry weight determination.

Analysis of variance was performed using SAS (Cary, N.C.). Spacing was tested for both linear and quadratic fit, and when significant, effects were indicated in the tables or text.

\section{Results and discussion}

Ear weight of early planted corn was affected by cultivar and spacing in three of four experiments (Tables 1-4).
Table 1. Effect of in-row spacing on ear weight, length and yield of the sweet corn cultivar 'Temptation' when grown in Eden Valley, New York, 1998.

\begin{tabular}{ccccc}
\hline \multirow{2}{*}{$\begin{array}{c}\text { In-row } \\
\text { spacing } \\
\text { (inches) }^{\mathrm{z}}\end{array}$} & $\begin{array}{c}\text { Ear wt } \\
(\mathrm{lb})\end{array}$ & $\begin{array}{c}\mathrm{Wt} \\
(\mathrm{lb})\end{array}$ & $\begin{array}{c}\text { Length } \\
\text { (inches) }^{\mathrm{x}}\end{array}$ & $\begin{array}{c}\text { Mield } \\
\text { (tons/acre) }\end{array}$ \\
\hline 7 & 1.71 & 1.19 & $7.30 \mathrm{c}$ & $8.3 \mathrm{a}$ \\
8 & 1.77 & 1.23 & $7.36 \mathrm{~b}$ & $8.0 \mathrm{ab}$ \\
9 & 1.83 & 1.24 & $7.43 \mathrm{a}$ & $7.0 \mathrm{~b}$
\end{tabular}

${ }^{\mathrm{z}} 1 \mathrm{inch}=2.54 \mathrm{~cm} ; 1 \mathrm{lb}=0.454 \mathrm{~kg} ; 1$ ton $/$ acre $=2.24 \mathrm{t} / \mathrm{ha}$.

${ }^{\mathrm{y}}$ After removal of outer husk, leaving only cob and kernels.

${ }^{\mathrm{x}}$ Mean values within the same column followed by same letter were not signficantly different at $P<0.05$, using Fishers Protected LSD.
In the 1998 trial, ear weight of 'Temptation' was not affected by in-row spacing (Table 1). In 1999, both 'Temptation' and 'Sweet Symphony' had similar ear weights at the 7 and 8 -inch inrow spacings, but ear weight increased at the 9-inch treatment (Table 2). In both 1998 and 1999, marketable yields were highest from the two most narrow in-row spacing treatments, as a result of similar ear weights coupled with higher plant populations at these spacings (Table 1,2). Thus, in-row spacings wider than 8 inches were not justified, based upon ear weight and yield.

In the 2000 and 2001 experiments, the 8 -inch spacing was compared to a narrow 6-inch in-row spacing, to determine if ear variability would be increased. The cultivars varied in the sensitivity to the narrow 6-inch in-row spacing, under two different early season conditions (Table 3 and 4). From 15 May to 15 June $2000,10.7$ inches $(27.2 \mathrm{~cm})$ of rain were recorded [average temperature of 59 $\left.{ }^{\circ} \mathrm{F}\left(16{ }^{\circ} \mathrm{C}\right)\right]$ compared with 4.5 inches $(11.4 \mathrm{~cm})$ [average temperature of $\left.63^{\circ} \mathrm{F}\left(18.3^{\circ} \mathrm{C}\right)\right]$ for the same period in 2001 . In both 2000 and 2001, 'Sweet Symphony' ear weight was significantly higher at the 8-inch in-row spacing compared with the 6-inch spacing (Fig. 1). This cultivar had the lowest ear weight of the cultivars when grown at 6-inch spacing in 2000 (Fig. 1).
In 2000, 'Temptation' ear weight was also higher at the 8-inch spacing, whereas in 2001, there was no change in ear weight between the two spacing treatments (Fig. 1). In contrast to the other two cultivars, ear weight of 'Seneca Spring' was similar at both spacsults suggested that ear development on 'Sweet Symphony' was more sensitive than 'Temptation' to plant competition at the 6-inch in-row spacing, while 'Seneca Spring' was relatively insensitive to competition at this narrow spacing. The competition at the 6 -inch in-row spacing also reduced the percentage of marketable ears, resulting in similar yield between the two spacing treatments (Tables 3 and 4 ).

Unlike ear weight, the husked ear weight (outer green husk removed) was similar across in-row spacings in all but 1 year (2000) (Tables $1-4)$. Thus, the observed differences in ear weight (ear with husk) resulted mostly from changes in the weight of the outer, green husk. Ear length, however, did vary in response to spacing, in three of four experiments (Tables 1-3). In 1998, ears were longer as in-row spacing increased from 7 to 9 inches (Table 1). In this experiment, however, all ears were longer than 7 inches and ings in both years (Fig. 1). These re-

Table 2. Effect of in-row spacing and cultivar on sweet corn ear weight and length, yield, percent marketability, and plant productivity when grown in Freeville, New York, 1999.

\begin{tabular}{|c|c|c|c|c|c|c|c|}
\hline \multirow[b]{2}{*}{ Factor } & \multirow{2}{*}{$\begin{array}{c}\text { Ear } \\
\text { wt (lb) }\end{array}$} & \multicolumn{3}{|c|}{ Husked ear ${ }^{\mathrm{y}}$} & \multirow{2}{*}{$\begin{array}{c}\text { Yield } \\
\text { (tons/acre) }\end{array}$} & \multirow{2}{*}{$\begin{array}{c}\text { Marketable } \\
\text { ears } \\
(\%)\end{array}$} & \multirow{2}{*}{$\begin{array}{c}\text { Barren } \\
\text { plants } \\
(\%)^{\mathrm{x}}\end{array}$} \\
\hline & & Wt (lb) & $\begin{array}{l}\text { Length } \\
\text { (inches) }\end{array}$ & $\begin{array}{l}\text { Longer than } \\
7 \text { inches }(\%)\end{array}$ & & & \\
\hline \multicolumn{8}{|c|}{ In row Spacing (inches) } \\
\hline 7 & 0.63 & 0.43 & 7.1 & 48 & 8.3 & 90 & 15 \\
\hline 8 & 0.63 & 0.45 & 7.2 & 58 & 7.9 & 93 & 9 \\
\hline 9 & 0.70 & 0.46 & 7.8 & 79 & 7.1 & 91 & 13 \\
\hline \multicolumn{8}{|l|}{ Cultivar } \\
\hline Sweet Symphony & 0.68 & 0.44 & 7.4 & 75 & 7.5 & 94 & 10 \\
\hline Temptation & 0.64 & 0.45 & 7.1 & 49 & 7.0 & 88 & 15 \\
\hline \multicolumn{8}{|l|}{ Significance levels } \\
\hline Spacing & $* *$ & $\mathrm{~ns}$ & $* *$ & $* *$ & $* *$ & ns & ns \\
\hline Cultivar & $* *$ & ns & $* *$ & $* *$ & $* *$ & $* *$ & $* *$ \\
\hline Cultivar x Spacing & $\mathrm{ns}$ & $\mathrm{ns}$ & ns & ns & ns & ns & ns \\
\hline
\end{tabular}

$1 \mathrm{inch}=2.54 \mathrm{~cm} ; 1 \mathrm{lb}=0.454 \mathrm{~kg} ; 1 \mathrm{ton} / \mathrm{acre}=2.24 \mathrm{t} / \mathrm{ha}$.

${ }^{\mathrm{y}}$ After removal of outer husk, leaving only cob and kernels.

${ }^{\mathrm{x}}$ Percent of plants not producing a marketable ear.

ns, *, ** Nonsignificant or signficant at $\mathrm{P}<0.05$ or 0.01 , respectively. 
Table 3. Effect of in-row spacing and cultivar on sweet corn ear weight and length, yield, percent marketability, and plant productivity when grown in Freeville, New York, 2000.

\begin{tabular}{|c|c|c|c|c|c|c|c|}
\hline \multirow[b]{2}{*}{ Treatment } & \multirow{2}{*}{$\begin{array}{c}\text { Ear } \\
\text { wt }(\mathrm{lb})^{\mathrm{z}}\end{array}$} & \multicolumn{3}{|c|}{ Husked ear ${ }^{\mathrm{y}}$} & \multirow{2}{*}{$\begin{array}{c}\text { Yield } \\
\text { (tons/acre) }\end{array}$} & \multirow{2}{*}{$\begin{array}{c}\text { Marketable } \\
\text { ears } \\
(\%) \\
\end{array}$} & \multirow{2}{*}{$\begin{array}{c}\text { Barren } \\
\text { plants } \\
(\%)^{\mathrm{x}} \\
\end{array}$} \\
\hline & & $\mathrm{Wt}(\mathrm{lb})$ & $\begin{array}{l}\text { Length } \\
\text { (inches) }\end{array}$ & $\begin{array}{l}\text { Longer than } \\
7 \text { inches (\%) }\end{array}$ & & & \\
\hline \multicolumn{8}{|c|}{ In-row spacing (inches) } \\
\hline 6 & 0.56 & 0.39 & 6.5 & 20 & 6.5 & 77 & 26 \\
\hline 8 & 0.62 & 0.43 & 6.9 & 34 & 6.5 & 87 & 15 \\
\hline \multicolumn{8}{|l|}{ Cultivar } \\
\hline Temptation & 0.64 & 0.43 & 6.9 & 31 & 7.1 & 88 & 20 \\
\hline Sweet Symphony & 0.56 & 0.37 & 6.3 & 12 & 6.1 & 80 & 24 \\
\hline Seneca Spring & 0.56 & 0.42 & 7.0 & 39 & 6.3 & 84 & 18 \\
\hline \multicolumn{8}{|c|}{ Significance of Differences } \\
\hline Spacing & $* *$ & $* *$ & $* *$ & $* *$ & ns & $* *$ & $* *$ \\
\hline Cultivar & $* *$ & $* *$ & $* *$ & $* *$ & $* *$ & ns & ns \\
\hline Cultivar*spacing & $*$ & ns & * & ns & ns & ns & ns \\
\hline
\end{tabular}

${ }^{\mathrm{z}} 1$ inch $=2.54 \mathrm{~cm}: 1 \mathrm{lb}=0.454 \mathrm{~kg}: 1$ ton $/$ acre $=2.24 \mathrm{t} / \mathrm{ha}$.

${ }^{y}$ After removal of outer husk. leaving only cob and kernels.

${ }^{\mathrm{x}}$ Percent of plants not producing a marketable ear.

ns, ${ }^{*},{ }^{* *}$ Nonsionificant or sionificant at the $\mathrm{P} \leftarrow 0$ ๑ and 001 resnectivelv

Table 4. Effect of in-row spacing and cultivar on sweet corn ear weight and length, yield, percent marketability, and plant productivity when grown in Freeville, New York, 2001.

\begin{tabular}{|c|c|c|c|c|c|c|c|}
\hline \multirow[b]{2}{*}{ Treatment } & \multirow{2}{*}{$\begin{array}{c}\text { Ear } \\
\text { wt (lb) }{ }^{\mathrm{z}}\end{array}$} & \multicolumn{3}{|c|}{ Husked ear ${ }^{\mathrm{y}}$} & \multirow{2}{*}{$\begin{array}{c}\text { Yield } \\
\text { (tons/acre) }\end{array}$} & \multirow{2}{*}{$\begin{array}{c}\text { Marketable } \\
\text { ears } \\
(\%)\end{array}$} & \multirow{2}{*}{$\begin{array}{c}\text { Barren } \\
\text { plants } \\
(\%)^{\mathrm{x}}\end{array}$} \\
\hline & & $\mathrm{Wt}(\mathrm{lb})$ & $\begin{array}{l}\text { Length } \\
\text { (inches) }\end{array}$ & $\begin{array}{l}\text { Longer than } \\
7 \text { inches }(\%)\end{array}$ & & & \\
\hline \multicolumn{8}{|l|}{ In-row spacing (inches) } \\
\hline 6 & 0.67 & 0.45 & 7.2 & 35 & 6.5 & 86 & 24 \\
\hline 8 & 0.70 & 0.47 & 7.3 & 59 & 6.3 & 91 & 17 \\
\hline \multicolumn{8}{|l|}{ Cultivar } \\
\hline Temptation & 0.70 & 0.47 & 7.6 & 49 & 6.7 & 87 & 22 \\
\hline Sweet Symphony & 0.71 & 0.46 & 7.1 & 57 & 6.9 & 91 & 19 \\
\hline Seneca Spring & 0.64 & 0.44 & 7.0 & 35 & 5.7 & 87 & 21 \\
\hline \multicolumn{8}{|c|}{ Significance of Differences } \\
\hline Spacing & * & $\mathrm{ns}$ & $\mathrm{ns}$ & $* *$ & ns & * & ns \\
\hline Cultivar & * & $\mathrm{ns}$ & $*$ & * & * & $\mathrm{ns}$ & ns \\
\hline Cultivar*spacing & * & $\mathrm{ns}$ & $\mathrm{ns}$ & ns & ns & $\mathrm{ns}$ & $\mathrm{ns}$ \\
\hline
\end{tabular}

\footnotetext{
${ }^{\mathrm{z}} 1 \mathrm{inch}=2.54 \mathrm{~cm} ; 1 \mathrm{lb}=0.454 \mathrm{~kg} ; 1$ ton $/$ acre $=2.24 \mathrm{t} / \mathrm{ha}$.

${ }^{\mathrm{y}}$ After removal of outer husk, leaving only cob and kernels.

${ }^{\mathrm{x}}$ Percent of plants not producing a marketable ear.

ns, *, ** Nonsignificant or significant at the $\mathrm{P} \leq 0.05$ and 0.01 , respectively.
}

changes in average ear length were very small. It was questionable if these differences would be noticeable to a buyer. In 1999, ear lengths were similar [7.1 inches $(18.2 \mathrm{~cm})$ average length] at the 7 and 8 -inch in-row spacing treatments but significantly longer at the 9-inch spacing. In 2000, 'Sweet Symphony' and 'Temptation' ears were shorter in the 6inch in-row spacing, while 'Seneca Spring' ear length was unaffected by spacing, similar to results for ear weight. In 2001, the spacing treatments had no effect on ear length of any cultivar. Based upon results for ear length and yield from 4 years of evaluation, the 8 -inch in-row spacing optimized both traits among these three cultivars.

The percentage of ears longer than 7 inches was calculated, as a measure of uniformity (Tables 24). In 1999, the percentage of ears longer than 7 inches was similar for the 7 and 8-inch in-row spacings, but increased significantly at the 9-inch spacing treatment where $79 \%$ of ears were longer than 7 inches (Table 2). Overall, most ears measured in 2000 were shorter than 7 inches (Table 3, Fig. 2). Only 4\% of 'Sweet Symphony' ears grown at the 6-inch in-row spacing were longer than 7 inches in 2000, and this cultivar had significantly more short ears than the other two cultivars at this narrow spacing (Fig. 2). In contrast, 'Sweet Symphony' had $40 \%$ of ears longer than 7 inches at this same narrow 6-inch in-row spacing in 2001 (data not shown). This variation in length between the 2 years was similar to observations for ear weight of this cultivar. The distribution of 'Seneca Spring' ear length was not affected by the narrow spacing treatments in 2000 (Fig. 2). Overall, the 8-inch in-row spacing, or a plant population of 26,000 plants/acre provided between $34 \%$ and $59 \%$ of ears longer than 7 inches (Tables 2-4). If the 2000 'Sweet Symphony' data was omitted, this range was $40 \%$ to $59 \%$. If the highest percentage of long ears was desired, wider in-row spacings (e.g., 9-inch) or 23,200 plants/acre should be considered. 

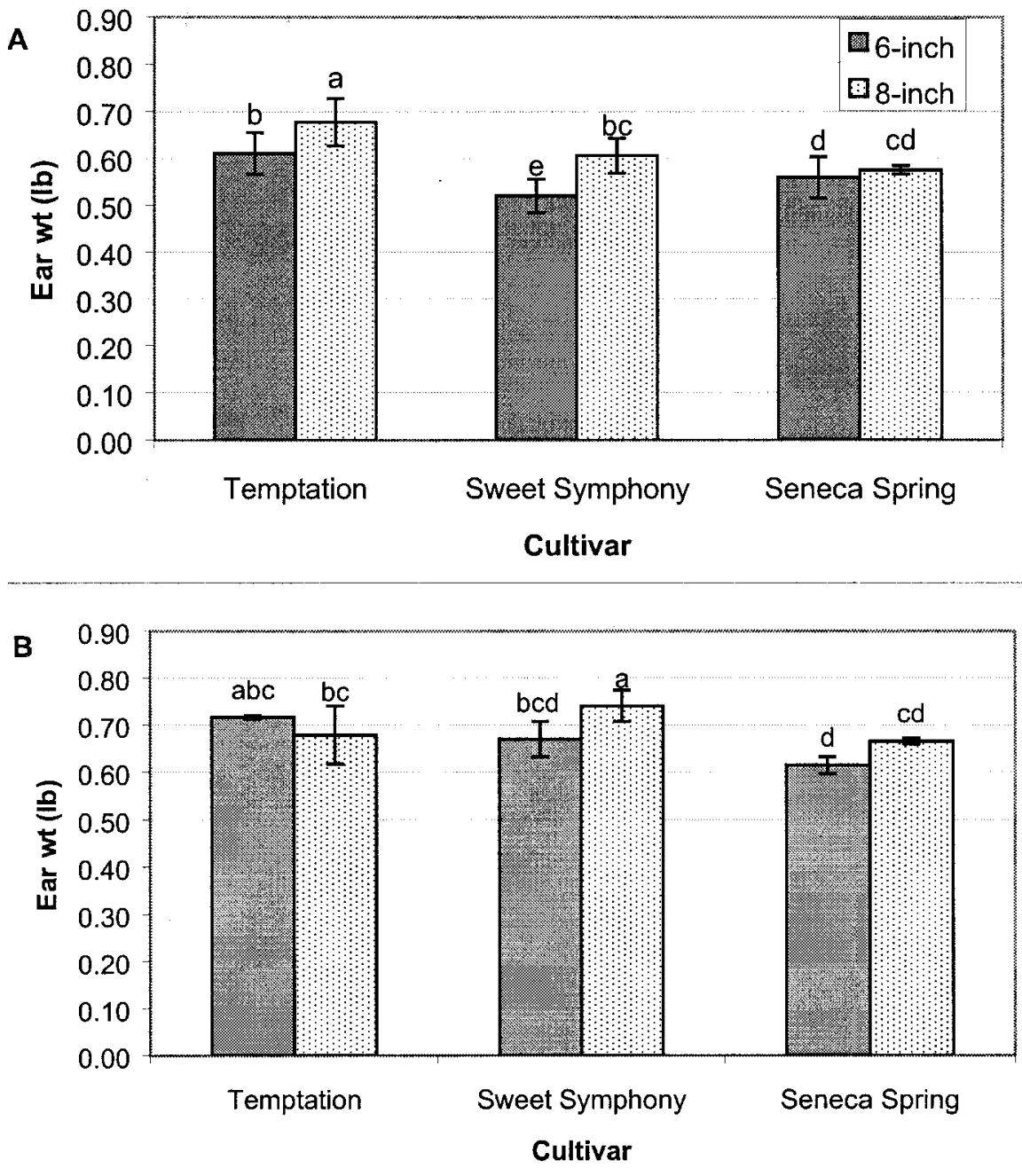

Fig. 1. Average ear weight $( \pm S E)$ of three sweet corn cultivar when grown at a 6inch $(15-\mathrm{cm})$ or 8-inch $(20-\mathrm{cm})$ in-row spacing in 2000 (A) and 2001 (B). Within each year, data bars with the same letter above them are not significantly different.

Results from main season sweet corn suggested that, generally, the yield of ears at least 7 inches long did not improve beyond populations of 20,000 plants/acre (Morris et al, 2000). While wider in-row spacings (or lower plant populations) enhanced the percent of ears that were long in early-planted corn, yields were reduced.

Differences in ear characteristics could be partially attributed to differences in plant biomass allocation within the ear and among leaves and stalks of the three cultivars grown in 2000 and 2001. Ear quality and yield of 'Seneca Spring' was not reduced by the 6-inch in-row spacing. 'Seneca Spring' had the lowest percent of the ear weight as husk (26\% in $2000, P<0.001 ; 30 \%$ in 2001 , $P<0.05)$ compared to both other varieties (34\% in 2000 and 2001). Allocation to the husk and ear length may be similarly affected by plant competition. Significant correlations were detected between the percentage of the earweight as husk and the ear length in $1999(P<$ $\left.0.05, R^{2}=0.57\right)$ and $2000\left(P<0.01, R^{2}\right.$ $=0.68)$. A separate cultivar evaluation of early-planted sweet corn (2001) detected a range in the percentage of ear weight as husk of $26 \%$ to $40 \%$ (unpublished data). Selection of cultivars that form ears having a minimum percentage of weight as husk (while still achieving good tip cover) should be further evaluated as a strategy to reduce risks of narrow spacing on ear weight and perhaps length. 'Seneca Spring' also had significantly lower per plant dry weight [ $1.3 \mathrm{oz}(36 \mathrm{~g})$ in 2000 and $1.1 \mathrm{oz}(30 \mathrm{~g})$ in 2001; $P<0.001$ both years] compared with the other two cultivars [average of $2.4 \mathrm{oz}(70 \mathrm{~g})$ in 2000 and $2.2 \mathrm{oz}$ $(62 \mathrm{~g})$ in 2001 ] indicating that it may be more efficient at partitioning biomass intoyield components. Previous research with su sweet corn types also found that smaller-sized cultivars were better adapted for close in-row spacing (Dolan and Christopher, 1952). Research on main season sweet corn indicated that the cultivar with the largest plant biomass required the lowest plant population to maximize large ears (Morris et al, 2000).

In previous research with an sh, cultivar, the percent of barren stalks increased from $8.8 \%$ at a 12 -inch in-row spacing to $20.2 \%$ at a 6 -inch in-row spacing (Hanna and Story, 1992). Similar results of increasing barrenness with closer in-row spacings were observed with processing su sweet corn (Andrew, 1967; Mack, 1978) and field corn plants (Carlone and Russell, 1987). In these studies, narrow in-row spacings did not consistently affect barrenness (Tables $2-4)$. In 2000, 9\% more plants were barren at the 6-inch in-row spacing compare to the 8 -inch treatment (Table 3). In 1999 and 2001, however, spacing had no significant effect on barrenness. Thus, competition between plants affected ear weights, but not the total production of ears for these cultivars.

\section{Conclusions}

Growers commonly increase plant populations of early-planted sweet corn to compensate for reduced plant vigor and stand in cold soils, theoretically reducing the risk of low marketable yield. Increasing plant populations did increase marketable yields of these three cultivars planted early in upstate New York, but the optimum population for maximizing yield varied by cultivar and season. The competition between plants at closer in-row spacings affected marketable ear weight and length in 3 years and percent marketable ears in 2 years of trials. The husked ear weight (outer green husk removed) was not affected by spacing treatments in 3 of 4 experiments, suggesting that yield differences were primarily due to changes in the outer husk weight. Average ear length varied by 0.2 to 0.6 inches and was decreased significantly at narrower in-row spacings. 'Seneca Spring' was more tolerant of a close inrow spacing of 6 inches. Selection of smaller sized cultivars such as 'Seneca Spring' when planting at close in-row spacings may reduce the risk of variable ears. While ears of this cultivar were shorter than the other two cultivars, performance was more consistent across different in-row spacings. For growers desiring around 50\% marketable ears with a minimum ear length of 
Fig. 2.

Percentage

of mea-

sured ears

(80 ears

\pm SE) that

were 14 to

$21 \mathrm{~cm}(5.5$

to 8.3

inches)

long for

each

cultivar

grown at

the 6-inch

$(15-\mathrm{cm})$ in-

row spacing

in 2000.

Length

measure-

ments were sorted into $1-\mathrm{cm}(0.4-$

inch) increments to evaluate percent

size distribution of marketable ears.

Statistically significance differences

in the percentages among cultivars at various ear lengths are indicated at $P$ $<0.05\left(^{*}\right)$ and $P<0.01\left({ }^{* *}\right)$ above ear length classes.

7 inches for 'Temptation' and 'Sweet Symphony', these studies suggest an optimal in-row spacing of 8 inches. At this spacing, these two cultivars provided a minimum 7 -inch ear for 2 of the 3 years. The improvement in average ear length did not justify in-row spacing beyond 8 inches or a target plant population of 26,000 plants/ acre, if high marketable yields were also desired.

\section{Literature cited}

Andrew, R.H. 1967. Population and spacing studies with sweet corn for canning. Univ. Wis. Agr. Expt. Sta. Bul. 28.

Bailey, R.M. 1941. Effect of plant spacing in yield, ear size and other characteristics of sweet corn. Proc. Amer. Soc. Hort. Sci. 38:546-553.

Carlone, M.R. and W.A. Russell. 1987. Response to plant densities and nitrogen levels for four maize cultivars from different eras of breeding. Crop Sci. 27:465-470.

Dolan, D.D. and E.P. Christopher. 1952. Plant spacing of sweet corn. Univ. R.I. Agr. Expt. Sta. Bul. 316. Contrib. 799.

Enzie, W.D. 1942. The relation of spacing to yield and to plant and ear development of some yellow sweet corn hybrids in New York. N.Y. State Agr. Expt. Sta. Bul. 700.

Freyman, S., M. Kaldy, G.C. Kozub, S. Dubetz, and W.T. Andrew. 1972. Spacing and fertilizer studies on sweet corn under irrigation in southern Alberta. Can. J. Plant Sci. 52:881-886.

Garrison, S. (ed.). 2002. Commercial vegetable production recommendations for New Jersey. Rutgers Coop. Ext. Publ. E001R.

Hanna, H.Y. and R.N. Story. 1992. Yield of super sweet corn as affected by $\mathrm{N}$ application timing, plant density, tiller removal and insecticides. Proc. Fla. State Hort. Soc. 105:343-344.

Mack, H.J. 1978. Within row spacing affects sweet corn. Ore. Veg. Dig. 27(2):12 .

Morris, T., G. Hamilton, and S. Harney. 2000. Optimum plant population for fresh market sweet corn in the Northeastern United States. HortTechnology 10:331336.

Orzolek, M.D., P.A. Ferretti, W.J. Lamont, K. Demchak, A.A. MacNab, J.M. Halbrendt, S.J. Fleischer, L.L. LaBorde, and W. Hoffman. 2001. Pennsylvania commercial vegetable production recommendations. Pa. State Coop. Ext. Publ. AGRS28.

Reiners, S., C. Petzholdt, and M.P. Hoffmann. 2002. Cornell integrated crop and pest management guidelines for commercial vegetable production. Cornell Coop. Ext. Publ. 142 MV.

Vittum, M.T., N.H. Peck, and A.F. Carruth. 1959. Response of sweet corn to irrigation, fertility level and spacing. N.Y. State Agr. Exp. Sta. Bul. 786.

White, J.M. 1984. Effect of plant spacing and planting date on sweet corn grown on muck soil in the spring. Proc. Fla. State Hort. Soc. 97:164-163.

Wolfe, D.W., F. Azanza, and J.A. Juvik. 1997. Sweet corn, p. 461-478. In: H.C. Wien (ed.). The physiology of vegetable crops. CAB Intl., Wallingford, U.K.

\section{Current Status of Human Issues in Horticulture in Korea}

\author{
Hye Ran Kwack ${ }^{1}$ and \\ Paula Diane Relf ${ }^{2}$
}

Additional IndeX words. alternative treatments, graduate program, horticultural therapy courses, mentally handicapped, research societies, research papers, mental illness, interdisciplinary studies, clinical implementation

Summary. As the level of urbanization has increased, many people in Korea have begun to recognize the beneficial effects of plants in our immediate surroundings and involvement in horticultural activities. Today, an increasing number of Koreans attempt to improve the quality of life and enhance educational effectiveness through horticultural activities. Kindergarten, elementary, middle, and high schools have initiated garden-based programs. Some universities include courses focusing on horticulture applications to human well-being in their regular graduate programs or in their social education curricula. A few general hospitals, psychiatric hospitals, and rehabilitation centers have begun applying horticulture as a means of treatment. Most of the research articles in Korea on various aspects of human issues in horticulture have been published since the foundation of two academic societies, the Korean Horticultural Therapy Association and the Korean Society for Plants, People, and Environment. These articles are primarily focused on the areas of school gardening, healing gardens, and psychological or physiological effects of horticultural activities. For the future development of human issues in horticulture in Korea, several areas need to be enhanced including: interdisciplinary studies of horticulture and social education; development of different skills, techniques,

${ }^{1}$ Postdoctoral, Department of Horticulture, Virginia Polytechnic Institute and State University, Blacksburg, VA 24061-0327.

${ }^{2}$ Professor, Department of Horticulture, Virginia Polytechnic Institute and State University, Blacksburg, VA 24061-0327. 